\title{
Comparative analysis of vitamin $A$ and iron content in food according to different food composition tables and nutritional evaluation software programs
}

\author{
Cristiane Barbosa CHAGAS ${ }^{1}$, Cláudia SAUNDERS ${ }^{1,2 *}$, Aline Bull Ferreira CAMPOS $^{1,2}$, \\ Jamile Lima NOGUEIRA², Cristina Lucia da SILVA² ${ }^{2}$ Priscila Dutra ALVES ${ }^{2}$, Andréa RAMALHO ${ }^{1,2}$
}

\begin{abstract}
The objective of this study was to analyze retinol equivalent and iron content in different food composition tables and nutritional evaluation software programs. A literature search was conduct to identify tables and software available in Brazil containing information about retinol equivalent and iron content that are currently used by nutritionists. Ten tables and five software programs were selected for this study. The methodology used to present the retinol equivalent and iron content was evaluated and no pattern to obtain such content was found in the tables and software programs analyzed. Only one of the tables had enough information for the calculation of retinol equivalents; this table is recommended to all Latin America As for the iron content, three of the tables analyzed stand out and therefore should be used; two of them are based on national foods and the other is recommended for use in all Latin America countries. None of the software programs evaluated use the conversion factors suggested by IVACG to assess the vitamin A content in foods. Special attention should be given to the content of iron provided in the software programs since they use tables as international sources and fortified foods.
\end{abstract}

Keywords: vitamin A; iron; food composition tables; nutritional evaluation software programs.

\section{Introduction}

Vitamin A deficiency (VAD) and iron deficiency are the two most important micronutrient deficiencies in the world (ERHARDT et al., 2004), and they have great impact on public health. Worldwide, about 250 million children are at risk of VAD and 2 billion people suffer from iron deficiency anemia (UNITED..., 2004; WEST JUNIOR, 2004).

According to the National Policy on Food and Nutrition (BRASIL, 2012), iron and vitamin A defciencies still persist as public health problems in Brazil and their main etiological factor is inadequate food intake (VAN JAARSVELD et al., 2005; BRASIL, 2012).

Inadequate dietary intake is the first stage of nutritional deficiency, and it can be detected by food intake assessment. Thus, dietary information is considered to be a premature prepathological indicator of nutritional deficiencies (BOWERING; LOWENBERG; MORRISON, 1980).

The term vitamin A comprises retinol (pre-formed vitamin A - animal foods) and all dietary carotenoids with trans-retinol biological activity. Carotenoids are called pre-vitamin forms because they can be converted into retinol (yellow and orange fruits and vegetables and dark green leaves). There are more than 600 forms of natural carotenoids and many of them have provitamin A activity, but food composition data are only available for three of them ( $\alpha$-carotene, $\beta$-carotene, and $\beta$-cryptoxanthin) (VAN JAARSVELD et al., 2005).
Humans efficiently absorb and use pre-formed vitamin A at rates of 70 to $90 \%$. More than $75 \%$ of the dietary vitamin A intake in Europe, the United States, and other industrialized countries is pre-formed. However, in developing countries, from about 70 to $90 \%$ of vitamin A comes from pro-vitamin, and beta-carotene is its main source. Depending on the individual status of vitamin $\mathrm{A}$ and other factors, including dietary ones, absorbing rates range from 20 to 50\% (PENNISTON; TANUMIHARDJO, 2005).

In order to correctly estimate vitamin A intake, biological activity and the efficiency in converting different forms of this vitamin in foods must be considered during dietary intake evaluations. According to the International Vitamin A Consultative Group - IVACG (INTERNATIONAL..., 2004), one microgram of retinol corresponds to twelve micrograms of betacarotene and to twenty-four micrograms of other carotenoids. Therefore, food composition tables used to estimate nutrients intake, in terms of vitamin A, must consider the retinol activity equivalent.

As for iron, its bioavailability in foods depends on the dietary composition. There are two types of dietary iron - heme and non-heme.

The heme-iron comprises approximately $10 \%$ of daily intake, while the non-heme-iron corresponds to approximately $90 \%$ (SHARP; SRAI, 2007). Heme-iron is found in the structure of the porphyrin ring, connected to the hemoglobin and the myoglobin, in meats and products which contain blood. Its

\footnotetext{
Received 10/8/2010

Accepted 10/12/2012 (004967)

1. Núcleo de Pesquisa em Micronutrientes, Instituto de Nutrição Josué de Castro, Universidade Federal do Rio de Janeiro - UFRJ, Av. Carlos Chagas Filho, 373, Bloco J, 2 andar, Edifício dos Institutos, Ilha do Fundão, CEP 21941-590, Rio de Janeiro, RJ, Brasil,e-mail: claudiasaunders@nutricao.ufri.br; claudiasaunders@osite.com.br

${ }^{2}$ Grupo de Pesquisa em Saúde Materna e Infantil, Núcleo de Pesquisa em Micronutrientes, Instituto de Nutrição Josué de Castro, Universidade Federal do Rio de Janeiro -

UFRJ, Av. Carlos Chagas Filho, 373, Bloco J, 2 andar, Edifício dos Institutos, Ilha do Fundão, CEP 21941-590, Rio de Janeiro, RJ, Brasil

${ }^{*}$ Corresponding author
} 
absorption rate is higher than that of non-heme-iron (25\%), and it is little influenced by dietary components which inhibit or promote inorganic iron absorption and is determined mainly by body reserves. Non-heme iron is found mainly in its ferric form; its quantity varies in vegetable foods, eggs, and fortified foods, and it accounts for about half of the iron content in meats. Its absorption rates varies from 2 to $20 \%$ and is determined not only by organic reserves, but also by its solubility in the proximal portion of the small bowels, which depends on the influence of dietary components ingested at the same time. The bioavailability of non-heme iron is increased by the presence of heme-iron and vitamin C; its absorption inhibitors include polyphenols found in certain vegetables, tannin (found in tea and coffee), phytates found in cereals such as oats, and calcium (LACERDA, 2009; PARRA et al., 2005).

This information should be considered when choosing a food composition table to evaluate diets in order to identify subjects which are at deficiency risk and to improve the association between the dietary indicator and other indicators used to identify and monitor nutritional deficiencies.

The objective of this study was to analyze information sources and methodologies used to determine the content of vitamin $\mathrm{A}$ and iron in different food composition tables and nutritional evaluation software programs in order to determine the best evaluation resource.

\section{Materials and methods}

A literature search or review was carried out in 2007 and 2008 to identify food composition tables and nutritional evaluation software programs available in Brazil containing information about the content of vitamin A and iron and have been used in clinical practice. The search was conducted in the Bireme and Pubmed databases and in the scielo virtual library as well as in university websites. The bibliographic references of each table and software were evaluated. The criteria used for this evaluation were the factors considered by the tables of food composition and software programs for the conversion of vitamin $A$ and the sources used for the determination of hemeiron and non-heme-iron.

According to these criteria, ten tables and five software programs were selected. The tables are: TACO (A) (UNIVERSIDADE..., 2006); Erhardt (B) (ERHARDT, 2004); Franco (C) (FRANCO, 2002); Pinheiro et al. (D) (PINHEIRO et al., 2005); Philippi (E) (PHILIPPI, 2002); UNIFESP (F) (UNIVERSIDADE..., 2001); USP (G) (UNIVERSIDADE..., 2004); IBGE (H) (INSTITUTO..., 1999); USDA (I) (GEBHARDT et al., 2006); and INCAP (J) (INSTITUTO..., 2006). The software programs are: NutWin (A) (UNIVERSIDADE..., 2005); Dietwin (B) (DIETWIN, 2008); Food Processor (C) (ELIZABETH..., 2008); Dietpro (D) (DIETPRO, 2008), and Avanutri (E) (AVANUTRI, 2008).

\section{Results}

Table 1 shows the information found in the food composition tables, and Table 2 shows the information found in the nutritional evaluation software programs.

With regard to vitamin $\mathrm{A}$, as can be seen in Table 1, two tables $(\mathrm{C}, \mathrm{F})$ and all software programs do not have a database to estimate the total content of vitamin A. Six tables (A, B, C, D, E, F) do not consider the conversion efficiency of other carotenoids

Table 1. Vitamin A and iron analysis in food composition tables available in Brazil.

\begin{tabular}{|c|c|c|}
\hline Table & Vitamin A analysis & Iron analysis \\
\hline A & Only considers retinol $(\mu \mathrm{g})$ & Evaluates total iron content (mg) \\
\hline B & Retinol and carotenoids (conversion factor $=12$ for most foods) & Does not evaluate iron \\
\hline $\mathrm{C}$ & Only considers retinol $(\mu \mathrm{g})$ & Evaluates total iron content (mg) \\
\hline $\mathrm{D}$ & Vitamin A in $\mu \mathrm{g}$ RE & Evaluates total iron content (mg) \\
\hline $\mathrm{E}$ & Vitamin A in Retinol ( $\mu \mathrm{g}$ RE). Converts IU into RE, no references or methodology. & Evaluates total iron content (mg) \\
\hline $\mathrm{F}$ & Vitamin A ( $\mu$ g RE ou IU) & Evaluates total iron content (mg) \\
\hline $\mathrm{H}$ & Retinol and carotenoids: 1:6 rate for beta-carotene activity & Evaluates total iron content (mg) \\
\hline I & Retinol and carotenoids: $1 \mu \mathrm{g}$ RE $=12 \beta$-carotene $=24$ other carotenoids & Evaluates total iron content (mg) \\
\hline $\mathrm{J}$ & Vitamin A: $1 \mu \mathrm{g} R E=12 \beta$-carotene $=24$ other carotenoids & Evaluates total iron content (mg) \\
\hline
\end{tabular}

RE: retinol equivalent, IU: International Unit, $\mu \mathrm{g}=$ micrograms, $\mathrm{mg}=$ milligrams.

Table 2. Vitamin A and iron analysis in nutritional evaluation software programs available in Brazil.

\begin{tabular}{ccc}
\hline Software & Vitamin A analysis & Iron analysis \\
\hline A & Retinol $(\mu \mathrm{g})$ & Evaluates total iron content $(\mathrm{mg})$ \\
$\mathrm{B}$ & Evaluates retinol and beta-carotene $(\mu \mathrm{g})$ & Evaluates heme iron $(\mathrm{mg})$ and non-heme iron $(\mathrm{mg})$ \\
$\mathrm{C}$ & Evaluates retinol and carotenoids $(\mu \mathrm{g})$ & Evaluates total iron content $(\mathrm{mg})$ \\
$\mathrm{D}$ & Evaluates retinol $(\mu \mathrm{g}$ RE retinol or IU) & Evaluates total iron content $(\mathrm{mg})$ \\
$\mathrm{E}$ & Retinol $(\mu \mathrm{g})$ & Evaluates total iron content $(\mathrm{mg})$ \\
\hline
\end{tabular}

RE: retinol equivalent, IU: International Unit, $\mu \mathrm{g}=$ micrograms, $\mathrm{mg}=$ milligrams. 
and attribute the same biological activity of beta-carotenoids to them or consider only retinol as a source of vitamin A. Two tables $(G, H)$ adopt outdated conversion factors of retinol and carotenoids in active vitamin A. Only two tables (I and J) consider currently used conversion factors for different forms of vitamin A according to IVACG (INSTITUTO..., 2004) (1 $\mu \mathrm{g}$ retinol equivalent corresponding to $12 \mu \mathrm{g}$ of beta-carotene and $24 \mu \mathrm{g}$ other carotenoids). As can be seen in Table 2, three software programs (A, D, E) consider only retinol as a source of vitamin $\mathrm{A}$; and one (B) considers retinol and beta-carotene; and another one $(\mathrm{C})$ considers retinol and carotenoids.

As for iron, according to Table 2, only one software program distinctively included information about the heme and nonheme iron content (B). In Table 1, two tables (B, G) do not analyze the iron content. In the other software programs and tables analyzed, the total iron content is presented.

Two tables (A, H) are based on Brazilian foods, and one of them $(J)$ is recommended for use in Latin America countries. The software programs present information which associates national and international tables and it is difficult to identify national foods.

\section{Discussion}

In order to evaluate vitamin A and iron intake, the Food Composition Table should be carefully chosen because an inadequate table or software can (negatively) compromise the entire dietary assessment, which alone is considered an indicator of risk for deficiency states, but when combined with other information and biochemical parameters may help define the diagnosis of nutritional deficiency.

Furthermore, the detection of inadequate intakes of these micronutrients (vitamin A and iron) may contribute to the prevention of their deficiencies, which are currently considered a major public health problem in many developing countries and cause many health risks to individuals because these nutrients play an important role in maintaining many vital functions such as growth, reproduction, immune function, and antioxidant function (BRASIL, 2009).

In a thorough selection, it is necessary to choose tables which clearly describe the analytical procedures used to determine the content of vitamin A and which consider the biological activity and the conversion efficiency of the different forms of vitamin A (1 $\mu \mathrm{g}$ retinol/ $12 \mu \mathrm{g}$ beta-carotene/ $24 \mu \mathrm{g}$ other carotenoids) (INTERNATIONAL..., 2004). Additionally, a distinction between the contribution of heme and non-heme iron in foods should be made. These measures increase the reliability of dietary intake evaluation.

Besides, it is essential to choose tables and software programs which have information about national foods. Although international tables have information about important foods, many of them are not available in Brazil, given the great variety of fortified foods in many countries, especially developed countries, because their use is an intervention strategy to reduce risks of micronutrient deficiencies, such as VAD and anemia, in the population (INTERNATIONAL..., 2002; BRASIL, 2005).
When checking the vitamin A content of the selected tables, it was observed that except for two tables (I and J), all the others had no information about the retinol and carotenoids based on current proportions recommended by IVACG (INTERNATIONAL..., 2004).

Therefore, the only food composition table that has enough information to calculate the content of vitamin $\mathrm{A}$, considering its different dietary forms, is the table from INCAP (INSTITUTO..., 2006). It analyzes foods available and usually consumed in Latin America and considers conversion factors currently used for different forms of vitamin A (SAUNDERS; RAMALHO; CHAGAS, 2009).

The table from the United States Department of Agriculture USDA (GEBHARDT et al., 2006) also has information about retinol and carotenoids based on current proportions recommended by the IVACG (INTERNATIONAL..., 2004). However, since it is an international table, it should be carefully used, considering that in many countries industrialized foods are fortified or enriched, and they have, as a consequence, higher levels of vitamin A and iron.

As for the iron content, two of the selected tables (B and G) did not evaluate this nutrient.

The TACO (UNIVERSIDADE..., 2006) and the IBGE (INSTITUTO..., 1999) tables are recommended to evaluate iron concentration in foods because they are based on national foods, the INCAP (INSTITUTO..., 2006) table is equally recommended since it is recommended for use in all Latin America countries. With regard to the USDA table (GEBHARDT et al., 2006), since it is an international table, the same observations made above for vitamin A are valid.

Among the software programs analyzed, they surely have many features which facilitate and speed professional practice. However, since they use a compilation of national and international tables as the source of information, they are not recommended to evaluate vitamin A because they adopt different conversion factors. As for iron, the software programs should be carefully used, mainly when analyzing industrialized and fortified foods.

\section{Conclusion}

Considering our findings, the INCAP table is recommended to evaluate the content of vitamin A in foods. The software programs evaluated do not consider the different forms of vitamin $\mathrm{A}$; therefore, caution is recommended when assessing the intake of this vitamin by the programs. The TACO, IBGE, and INCAP tables are recommended to evaluate the content of iron. The USDA table may be used, with special attention to industrialized and fortified foods. The same rule applies to the software programs used to analyze the content of iron. Dietary assessment is useful in clinical practice for the identification of individuals at risk of deficiencies in question; thus, the choice of tables known as Chemical Composition of Foods or nutritional evaluation software program must be made judiciously with respect to the content of vitamin A and iron, thus allowing diagnosis and appropriate nutrition intervention. 


\section{References}

AVANUTRI. versão 3.0 [software]. Disponível em: <http://www. avanutri.com.br>. Acesso em: 01 dez. 2008.

BOWERING, J.; LOWENBERG, R. L.; MORRISON, M. A. Nutritional studies of pregnant women in East Harlen. The American Journal of Clinical Nutrition, v. 33, p. 1987-1996, 1980. PMid:7416066.

BRASIL. Ministério da Saúde. Manual operacional do Programa Nacional de Suplementação de Ferro. Brasília: Ministério da Saúde, 2005. 28 p.

BRASIL. Ministério da Saúde. Boletim Carências NutricionaisDeficiêmcia de Vitamina A (DVA). 2. ed. Brasília: Ministério da Saúde, 2009.

BRASIL. Ministério da Saúde. Politica Nacional de Alimentação e Nutrição. Brasilia: Ministério da Saúde, 2012.

DIETPRO. Dietpro - Software de Avaliação Nutricional e Prescrição Dietética versão profissional. Viçosa. [software]. Disponível em: <http://www.dietpro.com.br/oque.htm>. Acesso em: $01 \mathrm{dez} .2008$.

DIETWIN. versão 2.0 [software]. Porto Alegre. Disponível em: $<$ http:// www.dietwin.com.br/>. Acesso em: 01 dez. 2008.

ELIZABETH STEWART HANDS AND ASSOCIATES - ESHA. Food Processor. versão 7.2 Salem. [software]. Disponível em: <http:// www.esha.com>. Acesso em: 01 dez. 2008.

ERHARDT, J. Printed version of the new vitamin A table. SIGHT AND LIFE Newsletter, v. 1, p. 25-34, 2004.

ERHARDT, J. G. et al. Combined measurement of ferritin, soluble transferrin receptor, retinol binding protein, and C-reactive protein by an inexpensive, sensitive, and simple sandwich enzyme-linked immunosorbent assay technique. Journal of Nutrition, v. 134, p. 3127-3132, 2004. PMid:15514286.

FRANCO, G. Tabela de composição química dos alimentos. 9. ed. São Paulo: Atheneu, 2002.

GEBHARDT, S. E. et al. Usda national nutrient database for standard reference. release 19. 2006. Disponível em: <http://www.ars.usda. gov/nutrientdata/>. Acesso em: 01 dez. 2008.

INSTITUTO BRASILEIRO DE GEOGRAFIA E ESTATÍSTICA - IBGE. Tabela de composição dos alimentos. 5. ed. ENDEF, IBGE, 1999.

INSTITUTO DE NUTRICIÓN CENTRO AMERICA Y PANAMÁ - INCAP. Tabla de composición de alimentos para uso en America Latina. 2006. Disponível em: < http://www.incap. org.gt/>. Acesso em: 01 dez. 2008.

INTERNATIONAL VITAMIN A CONSULTATIVE GROUP - IVACG. IVACG Statement. Maternal Night Blindness: A new indicator of vitamin A deficiency. USA: IVACG, 2002.

INTERNATIONAL VITAMIN A CONSULTATIVE GROUP - IVACG. Conversion factors for vitamin A and carotenoids. USA: IVACG, 2004.
LACERDA, E. M. A. Deficiência de Ferro no Grupo Materno-Infantil. In: ACCIOLY, E.; SAUNDERS, C.; LACERDA, E. M. A. Nutrição em Obstetrícia e Pediatria. 2. ed. Rio de Janeiro: Cultura Médica, 2009.

PARRA, B. E. et al. Evaluación de la educacion nutricional y un suplemento para prevenir la anemia durante la gestación. Biomedica, v. 25, p. 211-9, 2005. PMid:16022376.

PENNISTON, K. L.; TANUMIHARDJO, S. A. The acute and chronic toxic effects of vitamin A. The American Journal of Clinical Nutrition, v. 83, p. 191-201, 2006. PMid:16469975.

PHILIPPI, S. T. Tabela de composição de alimentos: Suporte para decisão nutricional. 2. ed. São Paulo: Coronário, 2002.

PINHEIRO, A. B. V. et al. Tabela para avaliação de consumo alimentar em medidas caseiras. 5. ed. São Paulo: Atheneu, 2005.

SAUNDERS, C.; RAMALHO, A.; CHAGAS, C. B. Indicadores da Deficiência de vitamina A. In: RAMALHO, A. Fome Oculta: diagnóstico, tratamento e prevenção. São Paulo: Atheneu, 2009. p. 123-136. PMid:18467136.

SHARP, P.; SRAI, S. K. The molecular mechanisms involved in intestinal iron absorption. World Journal of Gastroenterology, v. 13, n. 35, p. 4716-4724, 2007. PMid:17729393.

UNITED NATIONS CHILDREN'S FUND - UNICEF. Vitamin \& Mineral deficiency: a global progress report. UNICEF, Mar. 2004.

UNIVERSIDADE ESTADUAL DE CAMPINAS - UNICAMP. Tabela brasileira de composição de alimentos - TACO. versão 2. 2. ed. Campinas: UNICAMP/NEPA, 2006. 105 p.

UNIVERSIDADE FEDERAL DE SÃO PAULO - UNIFESP. Tabela de Composição Química dos alimentos. 2001. Disponível em: <http:// www.unifesp.br/dis/servicos/nutri/>. Acesso em: 1 dez. 2008.

UNIVERSIDADE FEDERAL DE SÃO PAULO - UNIFESP. Programa de Apoio a Nutrição - NutWin. Departamento de Informática em Saúde, 2005. [software]. Disponível em: <http://www.dis.unifesp.br/ produtos/nutwin/recursos $>$. Acesso em: $01 \mathrm{dez} .2008$.

UNIVERSIDADE DE SÃO PAULO - USP. Tabela Brasileira de Composição de alimentos. versão 4.1. 2004. Disponível em: <http:// www.fcf.usp.br/tabela/> Acesso em: 01 dez. 2008.

VAN JAARSVELD, P. J. et al. b-carotene-rich orange-fleshed sweet potato improves the vitamin A status of primary school children assessed with the modified-relative-dose-response test. The American Journal of Clinical Nutrition, v. 81, p. 1080-1087, 2005. PMid:15883432.

WEST JUNIOR, K. P. Vitamin A deficiency as a preventable cause of maternal mortality in undernourished societies: plausibility and next steps. International Journal of Gynecology \& Obstetrics, v. 85, p. S24-S27, 2004. Suplemento 1. 